\title{
DIFFERENCES IN CHROMATIC SENSITIVITY ESTIMATED USING STATIC AND DYNAMIC COLOUR STIMULI
}

\author{
Renārs Trukša\#, Kaiva Juraševska, Aija Livzāne, and Jānis Dzenis \\ Department of Optometry and Vision Science, Faculty of Physics and Mathematics, University of Latvia, \\ 1 Jelgavas Street, Rīga, LV-1004, LATVIA \\ \# Corresponding author, renars.truksa@lu.Iv
}

Communicated by Ivars Lācis

\begin{abstract}
The current study reports on a novel computerised colour vision test employing static and dynamic stimuli. The aim of the study was to assess if static and dynamic stimuli result in comparable chromatic discrimination thresholds when participant's age is taken into account. Participants $(n=20)$ were 21 to 77 years old, had normal colour vision and no history of any eye disease. They all participated in two sessions estimating chromatic sensitivity with static and dynamic stimuli, respectively, with six directions in colour space varying either along the red-green (RG) or yellow-blue (YB) directions. We found no significant differences in chromatic thresholds along a tritan axis obtained with static and dynamic stimuli. However, along protan and deitan axes, chromatic thresholds were lower if estimated using static stimuli than those estimated using the dynamic stimuli. As anticipated, chromatic sensitivity decreased with age and with greater chromatic sensitivity loss along the tritan confusion line. Research results suggest that differences between chromatic thresholds measured with static and dynamic stimuli become more apparent with increasing age of study participant.
\end{abstract}

Key words: computerised colour vision test, static and dynamic stimuli, psyhophysics.

\section{INTRODUCTION}

Approximately $8 \%$ Caucasian males and $0.5 \%$ females have some form of congenital colour vision deficiency; the condition is manifested as reduced ability to discriminate chromatic stimuli and, in some cases, achromatic stimuli from chromatic stimuli (Simunovic, 2010). To conduct a qualitative colour vision diagnosis for individuals in various age groups, it is necessary to evaluate appropriate performance of all age groups in colour vision tests. Setting average performance intervals for various age groups in each colour vision test, it is important to exclude observers with diverse conditions, such as diabetes (Muntoni et al., 1982; Wong et al., 2008), diabetic retinopathy (Barton, Fong, and Knatterud, 2004), glaucoma (for these patient's, colour perception inadequate for the age norm can frequently be observed) (Muntoni et al., 1982; Barton, Fong, and Knatterud, 2004; Wong et al., 2008), from further data processing. Previous research has shown that patients with type 2 diabetes demonstrate reduced colour discrimination for blue-yellow stimuli when tested with the Farnsworth-Munsell-100 hue test (FM-100), while the computerized Cambridge Colour Test (CCT) has demonstrated general chromatic sensitivity decrement in type 2 diabetes (Feitosa-Santana et al., 2010).

Several studies have confirmed that chromatic sensitivity changes depend on age (Kinnear and Sahraie, 2002;
Paramei and Oakley, 2014), and the highest chromatic sensitivity occurs at age 19-29 years (depending on the study). Typically colour sensitivity increases until 19-26 years of age and gradual impairment of chromatic sensitivity is observed after 26 years of age (Knoblauch et al., 2001; Paramei and Oakley, 2014; Barbur and RodriguezCarmona, 2015). Differences in chromatic sensitivity might be attributed to lack of maturity of the visual system in children and adolescents, and chromatic discrimination depends on the test design and nonverbal IQ (Kinnear and Sahraie, 2002; Cranwell et al., 2015).

As age increases, not only does the ability to discriminate colours in the blue-yellow axis decrease (which is explained by increased visible spectrum short wavelength absorption in the intraocular lens), but all visible spectrum transmission is reduced due to increase of intraocular lens thickness (Pokorny et al., 1987; Weale, 1988). It is important to emphasise that commercially available computerised colour vision test stimuli have dissimilar characteristics. For example, the CCT is based on static pseudoisochromatic plate stimuli principles, while the Colour Assessment and Diagnosis (CAD) test (Rodriguez-Carmona et al., 2005) is composed of dynamic stimuli moving across an achromatic background. When assessing changes in chromatic sensitivity due to aging, using different computerised stimuli, one cannot draw valid conclusions about the effect of stimulus 
temporal characteristics on chromatic sensitivity due to significant variations in stimulus design.

The aim of our study was to assess whether static and dynamic stimuli result in comparable chromatic discrimination thresholds when participant's age is taken into account. The option to include a dynamic component is foreseen without significantly changing overall test stimuli structure. Using our test stimuli, it is possible to directly evaluate the effect of the dynamic component on chromatic sensitivity.

\section{MATERIALS AND METHODS}

Participants. Twenty subjects with mean age $44 \pm 4$ years participated in the study, thirteen females and seven males. All participants had normal or corrected-to-normal visual acuity. Before computerised colour vision testing, colour vision of all participant was assessed with $4^{\text {th }}$ edition Richmond HRR pseudoisochromatic test plates (2012) and in eleven cases with an Oculus HMC anomaloscope (type 47720). History of ophthalmic diseases was collected for all participants, with special emphasis on retinal pathologies, glaucoma, cataracts, general illness like diabetes and neurological diseases. None of the participants were excluded on the basis of systemic or ocular diseases. The study was conducted in accordance with the guidelines of the Commission of Ethics of University of Latvia.

Materials. Each participant's chromatic sensitivity was assessed in two experimental sessions with dynamic and static stimuli. Chromatic stimuli were chosen to lie on confusion lines in CIE xyY colour space containing an achromatic point and corresponding confocal point (Birch, 1993). Measurements were made in 6 directions in colour space (from achromatic point along two directions of the protan, deutan, and tritan confusion lines). Chromatic stimuli were chosen for the closest possible match with theoretical confusion lines (see Equation 1 and Fig. 1). In Equation 1, s stands for point (xp, yp) distance to a confusion line, xp, yp - colour coordinates of the stimuli in CIE xyY colour space, $\mathrm{k}$ - confusion line slope, and $\mathrm{b}-$ confusion line intersection with Oy axis. For this study stimuli were chosen so that $\mathrm{s} \leq 0.001$ units in CIE xyY colour space.

$s=\frac{\left|y_{p}-b-x_{p} k\right|}{\sqrt{k^{2}+1}}$

Equation 1

Stimuli were presented on a Dell U2312 HM monitor calibrated with an Ocean Optics USB4000 spectrometer and Minolta CS-100A chroma meter. The test field was elliptically shaped with $9.1 \times 8.9$ degree of visual angle at 1 meter testing distance from the screen. The test field was composed of equilateral triangles alternately situated in 26 rows where each row was composed of up to 47 triangles. The chromatic stimulus was a hexagon and occupied a 2 degree of visual angle (Fig. 2). In the dynamic version, the chromatic stimuli travelled across the test field in one of four possible directions - up, down, right, or left. Demonstration of the dynamic stimuli occurred in 12 frames (frame re-

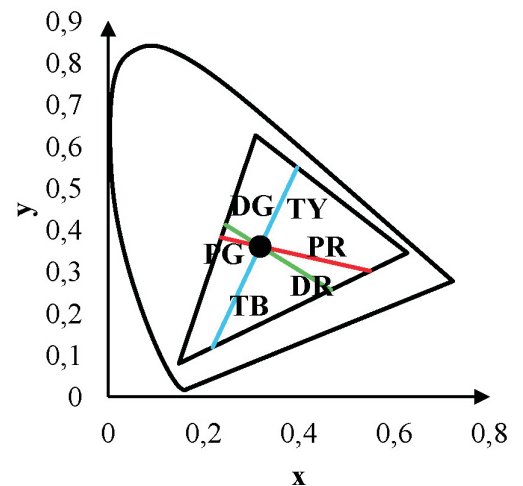

Fig. 1. CIExy diagram with colour direction codes along protan, deitan and tritan confusion lines, i.e. protan red (PR), protan green (PG), deitan green (DG), deitan red (DR), tritan blue (TB), tritan yellow (TY). Area limited by triangle represents the available monitor colour gamut. Monitor red (R) component colour coordinates $(0.6305,0.3329)$, green $(0.3166,0.6315)$ and blue (B) $(0.1432,0.0679)$. Monitor white point (black point in diagram) where chosen with coordinates $(0.3188,0.36)$. Confusion lines were selected to include corresponding confusion points protan $(0.75,0.25)$, deitan $(1.4,-0.4)$, tritan $(0,0.17)$ and monitor white point.

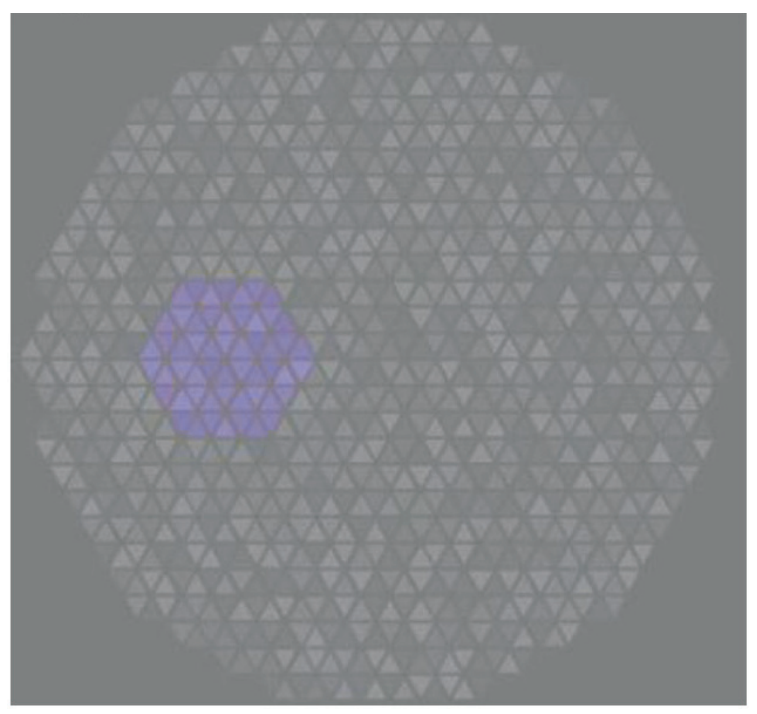

Fig. 2. Computerised test stimulus in the static version.

placement occurred each $100 \mathrm{~ms}$ ). In the static version, the identical hexagon stimulus was presented in four possible locations in relation to test field centre: top, bottom, right, or left. For individuals aged up to 69 years, stimuli were presented for $1000 \mathrm{~ms}$; for 70+ years old individuals, stimuli presentation duration was increased by $500 \mathrm{~ms}$. Participants were requested to respond about the movement direction of the dynamic stimulus or location of the static stimulus by pressing a corresponding button within 3 seconds after stimulus disappearance.

For achromatic and chromatic triangle elements composing the test field and stimuli, we chose five luminance levels: $12,14,16,18$, and $20 \mathrm{~cd} / \mathrm{m}^{2}$. The number of elements was held equal at all times at a given moment on the screen with certain luminance values, also for most elements in each subsequent frame. Luminance values were replaced leaving stimulus chromaticity as the only characteristic enabling stimulus discrimination in the dynamic stimuli version. 
Two psyhophysical methods (adaptive staircase and method of constant stimuli) were used to determine individual chromatic discrimination thresholds in six directions in colour space. The adaptive staircase procedure, 3 up 1 down modification (Levitt, 1971), was applied to measure approximate chromatic thresholds. In order to increase accuracy, the method of constant stimuli was applied. To determine the psychometric function, the probabilities of detecting chromatic stimuli of seven different saturation levels were ascertained. One of the chromatic stimuli saturation levels was chosen equivalent to the chromatic threshold value determined with the adaptive method and two stimuli saturation levels were chosen with detection probabilities $25 \%$ and $90 \%$. The remaining four saturation levels were equally spaced between the saturation level, which according to the adaptive method results corresponded to the chromatic threshold and stimuli with saturations levels that corresponded to $25 \%$ and $90 \%$ detection probability (Fig. 3). Data were approximated using the Boltzmann sigmoidal model, where the threshold value was estimated at probability $62.5 \%$ of correct responses.

To assess measurement repeatability, we compared corresponding chromatic sensitivity thresholds obtained in two experimental sessions. In the case of static stimuli, there was no difference between data obtained in two sessions, with one exception in the TY direction, while in case of dynamic stimuli we did not observe any difference between test results in both sessions (Table 1).

All statistical analysis was carried out by different variants of t-tests. The paired t-test was used to assess differences in chromatic thresholds between experimental sessions and chromatic thresholds obtained with static and dynamic stimuli within both groups. To compare chromatic thresholds between both groups, the independent two sample t-test was used. Relationship between chromatic thresholds measured with static and dynamic stimuli were tested by linear regression coefficients. To confirm correlation between chromatic thresholds measured with static and dynamic stimuli, the t-test was used to determine linear regression slope confidence intervals. Effect of the dynamic component on chromatic thresholds was assessed by analysing linear regression slope and intercept with the t-test. In cases when the

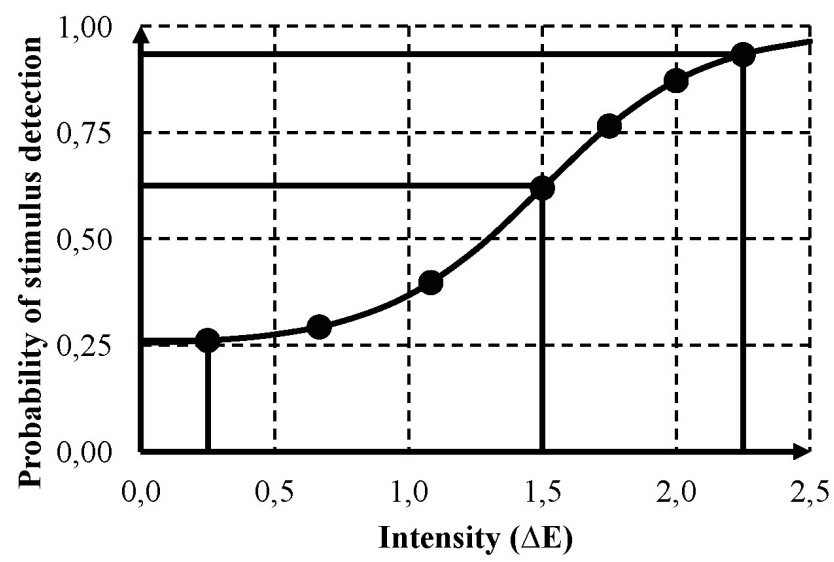

Fig. 3. Theoretical psychometric function.
STATISTICAL ANALYSIS OF CHROMATIC THRESHOLD MEASUREMENT REPEATABILITY WITH STATIC AND DYNAMIC TEST STIMULI BETWEEN TWO SESSIONS*

\begin{tabular}{l|c|c}
\hline $\begin{array}{c}\text { Colour } \\
\text { direction }\end{array}$ & Static stimuli & Dynamic stimuli \\
\hline PG & $t=-1.18>t_{0.05 ; 19}=-2.09$ & $t=0.73<t_{0.05 ; 19}=-2.09$ \\
PR & $t=-0.25>t_{0.05 ; 19}=-2.09$ & $t=-1.25>t_{0.05 ; 19}=-2.09$ \\
DG & $t=0.82<t_{0.05 ; 19}=-2.09$ & $t=1.08<t_{0.05 ; 19}=-2.09$ \\
DR & $t=0.75<t_{0.05 ; 19}=-2.09$ & $t=0.98<t_{0.05 ; 19}=-2.09$ \\
TY & $t=-2.48<t_{0.05 ; 19}=-2.09$ & $t=-0.08>t_{0.05 ; 19}=-2.09$ \\
TB & $t=-0.78>t_{0.05 ; 19}=-2.09$ & $t=0.13<t_{0.05 ; 19}=-2.09$ \\
\hline
\end{tabular}

* Significant differences in chromatic thresholds were found only in tritan yellow direction with static stimuli.

linear regression slope did not significantly differ from unity and intercept from zero, it was assumed that there was a direct linear relationship between chromatic thresholds measured with static and dynamic stimuli. In cases when the linear regression slope was significantly less than unity and intercept greater than zero, a direct linear relationship was rejected.

\section{RESULTS}

Chromatic sensitivity changes before and after age 40. Participants in the study were divided into two groups depending on their age: participants under age of 40 years $(n=$ $8,26 \pm 2$ years $)$ and participants older than 40 years $(n=12$, $54 \pm 3$ years). There were no significant differences in chromatic sensitivity thresholds measured with static and dynamic stimuli among participants under age 40 years, except for deitan green direction in colour space, while significant differences were found in the elderly patient group in colour directions protan red, deitan green, tritan yellow and blue (Table 2).

Statistical analysis showed that chromatic thresholds obtained with static stimuli differed between age groups for deitan and tritan confusion lines, and chromatic thresholds

Table 2

COMPARISONS BETWEEN CHROMATIC THRESHOLDS OBTAINED WITH DYNAMIC AND STATIC COMPUTERISED STIMULI*

\begin{tabular}{l|c|c}
\hline $\begin{array}{c}\text { Colour } \\
\text { direction }\end{array}$ & Age $(()$ & Age $(40)$ \\
\hline PG & $t=0.69<t_{0.05 ; 8}=2.36$ & $t=-1.50>t_{0.05 ; 11}=-2.20$ \\
PR & $t=-2.35>t_{0.05 ; 8}=-2.36$ & $t=-1.59>t_{0.05 ; 11}=-2.20$ \\
DG & $t=-3.10<t_{0.05 ; 8}=-3.10$ & $t=-4.05<t_{0.05 ; 11}=-2.20$ \\
DR & $t=-1.79>t_{0.05 ; 8}=-2.36$ & $t=-3.51<t_{0.05 ; 11}=-2.20$ \\
TY & $t=-0.11>t_{0.05 ; 8}=-2.36$ & $t=-3.01<t_{0.05 ; 11}=-2.20$ \\
TB & $t=-2.09>t_{0.05 ; 8}=-2.36$ & $t=-2.69<t_{0.05 ; 11}=-2.20$
\end{tabular}

* Chromatic thresholds in the younger group differed only in the deitan green colour direction whereas in the elderly group chromatic thresholds differed in all colour directions except deitan red and protan green. 

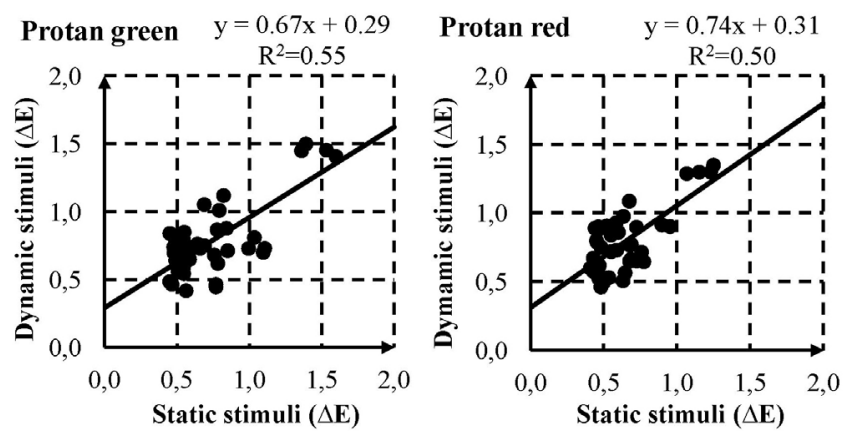

COMPARISON BETWEEN YOUNGER AND ELDERLY PARTICIPANT GROUP THRESHOLDS OBTAINED WITH STATIC AND DYNAMIC TEST STIMULI*

\begin{tabular}{l|c|c}
\hline $\begin{array}{c}\text { Colour } \\
\text { direction }\end{array}$ & Static stimuli & Dynamic stimuli \\
\hline PG & $t=3.34>t_{0.05 ; 18}=2.10$ & $t=3.22>t_{0.05 ; 18}=2.1$ \\
PR & $t=4.05>t_{0.05 ; 18}=2.10$ & $t=3.34>t_{0.05 ; 17}=2.1$ \\
DG & $t=1.22<t_{0.05 ; 17}=2.11$ & $t=2.88>t_{0.05 ; 17}=2.11$ \\
DR & $t=1.10<t_{0.05 ; 16}=2.12$ & $t=2.81>t_{0.05 ; 16}=2.12$ \\
TY & $t=3.22>t_{0.05 ; 12}=2.18$ & $t=3.58>t_{0.05 ; 12}=2.18$ \\
TB & $t=2.31>t_{0.05 ; 12}=2.18$ & $t=2.56>t_{0.05 ; 12}=2.18$
\end{tabular}

* Statistical analysis showed significant differences in chromatic thresholds between both age groups in deutan and tritan colour directions with static stimuli, and in all studied colour directions with dynamic test stimuli.

obtained with dynamic stimuli differed between age groups for all researched confusion lines (Table 3).

When chromatic thresholds of both age groups were compared, reduction in chromatic sensitivity was found with both test stimuli. However, differences in chromatic thresholds between both age groups were more prominent with dynamic test stimuli. In the elderly participant group, static and dynamic stimuli resulted in significant differences in chromatic sensitivity, which was not the case for the younger group. It seems that differences between chromatic thresholds obtained with static and dynamic stimuli become more prominent with increasing age, which suggests that mechanisms responsible for detection of static and dynamic stimuli degrade with different rate.

Differences between static and dynamic stimuli chromatic thresholds. In computerised colour vision testing, two quite distinctive and different colour vision tests are used - CAD and CCT. The key differences between both test stimuli designs are presence of dynamic noise and chromatic stimuli motion. To compare whenever chromatic thresholds depend on stimuli design, a novel computerised colour vision test design was introduced. Linear regression functions describing the relationship between dynamic and static thresholds were calculated to test for differences in thresholds obtained with the test stimuli. Linear regression functions showed moderate to high correlation between chromatic thresholds obtained with static and dynamic test stimuli (Fig. 4). Regression functions for protan and deitan deviated from a direct linear relationship; chromatic thresholds obtained with dynamic stimuli were higher than chromatic thresholds obtained with static stimuli (Table 4). The regression function for tritan blue colour direction indicated a direct linear relationship between chromatic thresholds obtained with the computerised stimuli. Tritan yellow regression function slightly differ from a direct linear relationship, i.e. the regression model slope was significantly higher than unity, which implied that chromatic thresholds measured with static stimuli are lower than chromatic thresholds measured with dynamic stimuli. The results showed that the dynamic component had a measurable in-
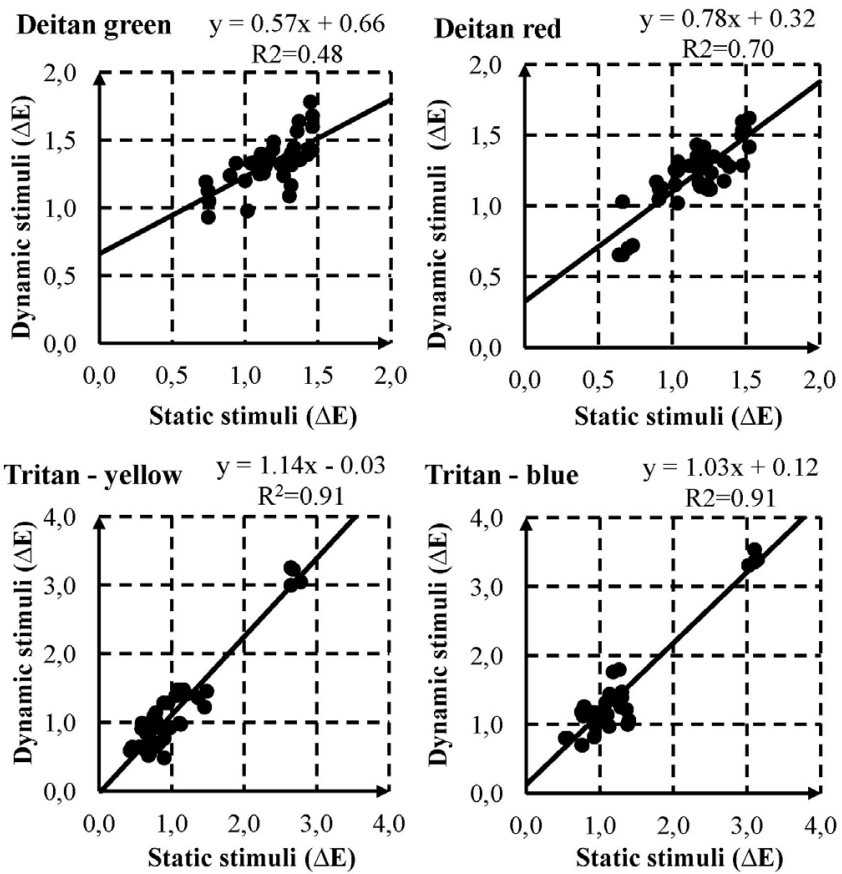

Fig. 4. Regression analyses chromatic discrimination thresholds obtained with dynamic and static stimuli.

fluence on colour perception mechanisms responsible for stimulus perception along protan and deitan confusion lines, whereas effect of the dynamic component on tritan stimuli perception was significantly less.

Deviation in a direct linear relationship between chromatic thresholds for protan and deitan measured with static and dynamic stimuli cannot be explained by performance differences between both age groups, since linear regression functions for tritan colour directions did not deviate from a direct linear relationship. It can be speculated that the YB mechanism is less susceptible to test stimuli dynamic properties than RG mechanisms, as tritan stimuli were chosen along a confusion line with slope 67.54 degrees, which corresponds to the $\mathrm{YB}$ mechanism and yields zero $\mathrm{L}$ and $\mathrm{M}$ cone contrast.

Anomaloscope and computerized colour test result comparison. Colour vision was evaluated for eleven of twenty participants with anomaloscope and computerised colour vision tests. Significant correlations were not found between the anomaloscope matching range and chromatic thresholds obtained with the computerised colour vision test, confirming the poor correlations obtained in previous studies 
STATISTICAL ANALYSIS OF LINEAR REGRESSION MODEL COEFFICIENTS

\begin{tabular}{ll|c|c|c|c}
\hline $\begin{array}{c}\text { Colour } \\
\text { direction }\end{array}$ & Variables & Coefficient & SE & 95\% CI & $p$ \\
\hline PG & slope & 0.74 & 0.01 & 0.50 to 0.98 & $<0.05$ \\
& intercept & 0.31 & 0.08 & 0.15 to 0.48 & $<0.05$ \\
\hline \multirow{2}{*}{ PR } & slope & 0.67 & 0.10 & 0.47 to 0.86 & $<0.05$ \\
& intercept & 0.29 & 0.08 & 0.13 to 0.45 & $<0.05$ \\
\hline \multirow{2}{*}{ DG } & slope & 0.78 & 0.08 & 0.61 to 0.94 & $<0.05$ \\
& intercept & 0.32 & 0.10 & 0.13 to 0.52 & $<0.05$ \\
\hline \multirow{2}{*}{ DR } & slope & 0.57 & 0.10 & 0.37 to 0.76 & $<0.05$ \\
& intercept & 0.66 & 0.12 & 0.43 to 0.90 & $<0.05$ \\
\hline \multirow{2}{*}{ TY } & slope & 1.14 & 0.06 & 1.02 to 1.26 & $<0.05$ \\
& intercept & -0.03 & 0.07 & -0.18 to 0.12 & ns \\
\hline \multirow{2}{*}{ TB } & slope & 1.01 & 0.08 & 0.84 to 1.19 & $<0.05$ \\
& intercept & 0.14 & 0.11 & -0.09 to 0.37 & ns
\end{tabular}

Linear regression models describe relationship between chromatic threshold values obtained with static and dynamic test stimuli. Linear regression models for protan and deitan colour directions deviate from a direct linear relationship which implies that chromatic thresholds measured with dynamic stimuli are higher than chromatic thresholds measured with static stimuli. The regression model for the tritan blue colour direction confirms direct linear relationship, confirmed by slope equal to unity and intercept zero. The regression model obtained for the tritan yellow colour direction slightly differed from a linear regression model implying that chromatic thresholds measured with static stimuli are higher than when measured with dynamic stimuli. ns - not statistically significant.

(Barbur et al., 2008). Linear regression functions between chromatic thresholds measured with computerised stimuli and the anomaloscope matching range indicated that slope did not significantly differ from 0 , thereby confirming lack of correlation between anomaloscope matching range and chromatic thresholds measured along protan and deitan confusion lines (Table 5).

\section{DISCUSSION}

In colour vision experiments, patients with normal colour vision are often perceived as a homogeneous group. However, there is abundant evidence that individuals with normal colour vision have considerable variability in estimated scores (Baraas, 2008; Rodriguez-Carmona et al., 2008). It is well known that women with trichromatic colour vision may have more than two spectrally different photopigments in the middle and long ranges of the visible light spectrum (Jordan and Mollon, 1993; Sun and Shevell, 2008). It is also known that there are at least two $\mathrm{L}$ and $\mathrm{M}$ photopigment versions among men and women (Neitz and Jacobs, 1990; Neitz et al., 1993). Photopigments have not only different absorption spectra but also optical density (Elsner et al., 1993; Renner et al., 2004) and relative quantities of L and $\mathrm{M}$ pigments in the retina, which may affect colour perception (Miyahara et al., 1996; Bieber et al., 1998; Kremers et al., 2000). Colour vision test results might be affected by the above mentioned factors, and also by preretinal absorption properties, particularly by intraocular lens absorption.
CORRELATION ANALYSIS BETWEEN CHROMATIC THRESHOLDS MEASURED WITH COMPUTERISED TEST STIMULI AND THE ANOMALSCOPE MATCHING RANGE*

\begin{tabular}{l|c|c}
\hline $\begin{array}{c}\text { Colour } \\
\text { direction }\end{array}$ & Static stimuli & Dynamic stimuli \\
\hline $\mathrm{PZ}$ & $t=0.37<t_{0.05 ; 10}=2.26$ & $t=0.93<t_{0.05 ; 10}=2.26$ \\
$\mathrm{PR}$ & $t=0.59<t_{0.05 ; 10}=2.26$ & $t=1.15<t_{0.05 ; 10}=2.26$ \\
$\mathrm{DG}$ & $t=0.01<t_{0.05 ; 10}=2.26$ & $t=0.06<t_{0.05 ; 10}=2.26$ \\
$\mathrm{DR}$ & $t=0.53<t_{0.05 ; 10}=2.26$ & $t=0.25<t_{0.05 ; 10}=2.26$ \\
\hline
\end{tabular}

* Correlation analysis suggests that there is no correlation between anomaloscope matching rage and chromatic thresholds measured with computerised test stimuli.

To successfully evaluate chromatic sensitivity changes with age or during illness, which may affect colour vision, it is necessary to use a reliable method with high measurement repeatability. In order to use our computerised colour test as a diagnostic method, it is necessary to carry out additional experiments with a larger participant group in various age intervals (with and without colour vision deficiency), as well as with persons who have systemic or ocular diseases that affect colour vision.

In spite of the shortcomings, we were able to demonstrate decrease in chromatic sensitivity with age along protan, deitan and tritan confusion lines and differences between hromatic thresholds measured with static and dynamic stimuli. No significant differences were found in the younger participant group in chromatic thresholds obtained with static and dynamic stimuli in most colour directions, which was in agreement with other studies (Barbur, 2004). Differences in chromatic sensitivity thresholds measured with static test stimuli were observed between the age groups in four of six colour directions. This was expected, as chromatic sensitivity has been shown to decrease with age (Paramei, 2012; Paramei and Oakley, 2014). Similarly, for dynamic stimuli, the elderly participant group showed higher chromatic thresholds for the studied colour directions, as found in other studies (Barbur and RodriguezCarmona, 2015). However, in the elderly participant group, chromatic thresholds obtained with static and dynamic stimuli significantly differed for all studied colour directions; chromatic thresholds measured with dynamic test stimuli were significantly higher. The above indicates that the estimated chromatic sensitivity decline differs depending on whether chromatic thresholds are measured with dynamic or static stimuli. The results suggest that motion perception mechanisms responsible for coloured stimuli movement perception decreases faster than sensitivity of mechanisms necessary for static coloured stimuli perception. It has been suggested that chromatic thresholds obtained with dynamic stimuli may be higher than chromatic thresholds measured with static stimuli due to additional noise in nervous pathways introduced by a flickering background (Regan et al., 1994). 
To explore differences in dynamic properties along protan, deitan, and tritan confusion lines, we compared dynamic and static chromatic thresholds. Our results suggest that the stimulus dynamic component does not have a significant effect on chromatic thresholds when measured along tritan colour directions. Linear regression functions were derived to describe relationships between chromatic thresholds measured with static and dynamic stimuli for several colour directions. The linear regression coefficients for protan and deitan suggested lack of a direct linear relationship, as linear regression slopes were significantly less than unity and intercepts significantly differed from zero. The obtained results might be explained by increased chromatic thresholds among elderly participants, i.e. elderly participants show significant differences between static and dynamic test results. However, in tritan colour directions, the linear regression intercepts did not significantly differ from zero and the slopes were equal or larger than unity. This contradicted the expected results, but might be explained by reduced dynamic properties of the blue-yellow mechanism compared to the red-green colour opponent mechanism (Gegenfurtner and Hawken, 1995). However, to raise general conclusions on the effect of the dynamic component on the blue-yellow colour mechanism, it is necessary to determine if the described effect occurs different dynamic stimulus settings.

The results of our study suggest that chromatic thresholds along tritan confusion lines are less affected by the dynamic component than chromatic thresholds obtained along protan and deitan confusion lines. This was unexpected, as mechanisms responsible for tritan stimuli perception are considered inferior to mechanisms for protan and deutan stimuli perception. The estimated chromatic thresholds within and between both age groups suggest that the decrease in chromatic sensitivity due to aging is more prominent when chromatic sensitivity is assessed with dynamic stimuli. However, additional studies with more participants and stimuli settings are needed to confirm the obtained results.

\section{REFERENCES}

Baraas, R. C. (2008). Poorer color discrimination by females when tested with pseudoisochromatic plates containing vanishing designs on neutral backgrounds. Vis. Neurosci., 25 (3), 501-505.

Barbur, J. L. (2004). 'Double-blindsight' revealed through the processing of color and luminance contrast defined motion signals. Progr. Brain Res., 144, 243-259.

Barbur, J. L., Rodriguez-Carmona, M. (2015). Color vision changes in normal aging. In: Elliott, A. J. Fairchild, M. D., Franklin, A. (eds.). Handbook of Color Psychology. Cambridge University Press, UK, pp. 180-196.

Barbur, J. L., Rodriguez-Carmona, M., Harlow, J. A., Mancuso, K., Neitz, J., Neitz, M. (2008). A study of unusual Rayleigh matches in deutan deficiency. Vis. Neurosci., 25 (3), 507-516.

Barton, F. B., Fong, D. S., Knatterud, G. L. (2004). Classification of Farnsworth-Munsell 100-hue test results in the early treatment diabetic retinopathy study. Amer. J. Ophthalmol., 138 (1), 119-124.

Bieber, M. L., Kraft, J. M., Werner, J. S. (1998). Effects of known variations in photopigments on $\mathrm{L} / \mathrm{M}$ cone ratios estimated from luminous efficiency functions. Vis. Res., 38 (13), 1961-1966.
Birch, J. (1993). Diagnosis of Defective Color Vision. Oxford University Press, New York. 187 pp. (at p. 37).

Cranwell, M. B, Pearce, B., Loveridge, C., Hurlbert, A. C. (2015). Performance on the Farnsworth-Munsell 100-Hue Test is significantly related to nonverbal IQ. Investig. Ophthalmol. Vis. Sci., 56 (5), 3171-3178.

Elsner, A. E., Burns, S. A., Webb, R. H. (1993). Mapping cone photopigment optical density. J. Opt. Soc. Amer. A, 10 (1), 52-58.

Feitosa-Santana, C., Paramei, G. V., Nishi, M., Gualtieri, M., Costa, M. F., Ventura, D. F. (2010). Color vision impairment in type 2 diabetes assessed by the D-15d test and the Cambridge Colour Test. Opthalm. Physiol. Opt., 30 (5), 717-723.

Gegenfurtner, K. R., Hawken, M. J. (1995). Temporal and chromatic properties of motion mechanisms. Vis. Res., 35 (11), 1547-1563.

Jordan, G., Mollon, J. D. (1993). A study of women heterozygous for colour deficiencies. Vis. Res., 33 (11), 1495-1508.

Kinnear, P. R., Sahraie, A. (2002). New Farnsworth-Munsell 100 hue test norms of normal observers for each year of age 5-22 and for age decades 30-70. Brit. J. Ophthalmol., 86 (12), 1408-1411.

Knoblauch, K., Vital-Durand, F., Barbur, J. L. (2001). Variation of chromatic sensitivity across the life span. Vis. Res., 41 (1), 23-36.

Kremers, J., Scholl, H. P. N., Knau, H., Berendschot, T. T. J. M., Usui, T., Sharpe, L. T. (2000). L/M cone ratios in human trichromats assessed by psychophysics, electroretinography, and retinal densitometry. J. Opt. Soc. Amer. A, 17 (3), 517-526.

Levitt, H. (1971). Transformed up-down methods in psychoacoustics. J. Acoust. Soc. Amer., 49 (2), 467-477.

Miyahara, E., Pokorny, J., Smith, V. C., Baron, R., Baron, E. (1996). Color vision in two observers with highly biased LWS/MWS cone ratios. Vis. Res., 38 (4), 601-612.

Muntoni, S., Serra, A., Mascia, C., Songini, M. (1982). Dyschromatopsia in diabetes mellitus and its relation to metabolic control. Diabetes Care, 5 (4), $375-378$.

Neitz, J., Jacobs, G. H. (1990). Polymorphism in normal human color vision and its mechanism. Vis. Res., 30 (4), 621-636.

Neitz, J., Neitz, M., Jacobs, G. H. (1993). More than three different cone pigments among people with normal color vision. Vis. Res., 33 (1), 117-122.

Paramei, G. V. (2012). Color discrimination across four life decades assessed by the Cambridge Colour Test. Opt. Soc. Amer., 29 (2), A290-A297.

Paramei, G. V., Oakley, B. (2014). Variation of color discrimination across the life span. J. Opt. Soc. Amer. A, 31 (4), A375-A384.

Pokorny, J., Smith, V. C., Lutze, M. (1987). Aging of the human lens. Appl. Opt., 26 (8), 1437-1440.

Regan, B. C., Reffin, J. P., Mollon, J. D. (1994). Luminance noise and the rapid determination of discrimination ellipses in colour deficiency. Vis. Res., 34 (10), 1279-1299.

Renner, A. B., Knau, H., Neitz, M., Neitz, J., Werner, J. S. (2004). Photopigment optical density of the human foveola and a paradoxical senescent increase outside the fovea. Vis. Neurosci., 21 (6), 827-834.

Rodriguez-Carmona, M, Sharpe, L. T., Harlow, J. A., Barbur, J. L. (2008) Sex-related differences in chromatic sensitivity. Vis. Neurosci., 25 (3), 433-440.

Rodriguez-Carmona, M. L., Harlow, A. J., Walker, G., Barbur, J. L. (2005). The variability of normal trichromatic vision and the establishment of the "normal" range. In: Proceedings of 10th Congress of the International Colour Association, 8-13 May 2005, Granada, pp. 979-982.

Simunovic, M. P. (2010). Colour vision deficiency. Eye, 24 (5), 747-755. 
Sun, Y., Shevell, S. K. (2008). Rayleigh matches in carriers of inherited color vision defects: The contribution from the third L/M photopigment. Vis. Neurosci., 25 (3), 455-462.

Received 10 November 2016

Accepted in the final form 3 October 2017
Weale, R. A. (1988). Age and the transmittance of the human crystalline lens. J. Physiol., 395 (1), 577-587.

Wong, R., Khan, J., Adewoyin, T., Sivaprasad, S., Arden, G. B., Chong, V. (2008). The ChromaTest, a digital color contrast sensitivity analyzer, for diabetic maculopathy: A pilot study. BioMed Central, 8 (5), 1-6.

\section{HROMATISKĀS JUTĪBAS ATŠKIIRĪBAS, KAS NOSKAIDROTAS AR STATISKIEM UN DINAMISKIEM KRĀSU STIMULIEM}

Pētījuma ietvaros izveidots datorizēts testa stimuls, kas ietver gan statisku, gan dinamisku testa stimula režīmu. Mērījumi veikti ar mērki noskaidrot, vai hromatiskās jutības sliekšņu vērtības, kas novērtētas ar statisku un dinamisku testa stimulu, ir būtiski atškirīgas. Pētījumā piedalījās 20 dalībnieki vecumā no 21 līdz 77 gadiem. Nevienam no pētījuma dalībniekiem iepriekš nav konstatēti krāsu redzes deficīti vai acu saslimšanas, kas var ietekmēt hromatisko jutību. Visi pētījuma dalībnieki piedalījās divās mērījumu sesijās, kur katrā no tām hromatiskā jutība tika izvērtēta ar statiskiem un dinamiskiem stimuliem sešos virzienos krāsu telpā, kas atbilst sarkani-zaļajiem (RG) un dzelteni-zilajiem (YB) krāsu virzieniem. Tritanopijas krāsu virzienos būtiskas hromatiskās jutības atškirības ar statiskiem un dinamiskiem stimuliem netika konstatētas, savukārt ievērojamas atšķirības tika apstiprinātas protanopijas un deiteranopijas krāsu virzienos ar statiskiem un dinamiskiem stimuliem, proti, zemākas hromatisko sliekšnu vērtības tika konstatētas ar statiskiem testa stimuliem. Tika apstiprināta hromatiskās jutības samazināšanās, pieaugot vecumam, un straujāka hromatiskās jutības samazināšanās tritanopijai atbilstošos krāsu virzienos. Balstoties uz pētījuma rezultātiem, tiek ierosināts, ka atšķirības starp statisku un dinamisku krāsu redzes testu rezultātiem kḷust ievērojamākas, pieaugot pacientu vecumam. 